\title{
ANALISIS TIPOLOGI TUTUPAN VEGETASI SEBAGAI DASAR PENYUSUNAN STRATEGI RESTORASI DI AREA IUPHHK-RE PT REKI
}

\section{Typological of Vegetation Cover Analysis as the Basis Strategy of Restoration on IUPHHK-RE PT REKI}

\author{
Nining Nurfatma ${ }^{\mathrm{a}}$, Prijanto Pamoengkas ${ }^{\mathrm{b}}$, Ika Heriansyah ${ }^{\mathrm{c}}$ \\ a Program Studi Silvikultur Tropika, Sekolah Pascasarjana IPB-nining.nurfatma@gmail.com \\ ${ }^{b}$ Departemen Silvikultur, Fakultas Kehutanan, Institut Pertanian Bogor, Kampus IPB Darmaga, Bogor 16680 \\ ${ }^{c}$ Divisi Silvikultur, Litbang Kehutanan, Gunung Batu, Bogor 16610
}

\begin{abstract}
Harapan rainforest situated in South Sumatera is a restoration area of PT REKI company that highly susceptible to land conversion. The problem faced in the effort of restoration is the restorated area that is too large and has not been tested any silvicultural techniques. The condition of land cover is the basic information that could be used as a reference in the preparation of restoration strategy. The study aimed to determine the level of damage, the condition of the ecosystem, appropriate silvicultural techniques, and plant species restoration priorities. The used methods were analysis of vegetation in 4 typologies (secondary forest, old shrub, young shurb, former akasia plantations). The order of area with the level of damage from the lowest to the highest were: the typology of secondary forest, old shurb, young shrub, and former akasia plantation, respectively. The typology of secondary forests had the highest value of diversity, richness, and evenness ( $H^{\prime}>3, D m g>5$, and $\left.E>0.6\right)$. Relationship between former akasia plantations typology and another tipologies was not germane (euclidean distance> 3.31), and the relationship between seedling and trees in all typologies (with the exception of former akasia plantations) was very high $(r>0.9)$. Silvicultural techniques that could be done include eradicating A. mangium in the former akasia plantation and planting in the all typologies with the exception of secondary forest. The plants that could be used for restoration are Macaranga sp., K.malaccensis, Nephelium sp., P.gutta, H.mengarawan, S.leprosula.
\end{abstract}

Keywords: Harapan Rain Forest, Silviculture Techniques, Restoration

(Diterima: 07-10-2016; Disetujui: 08-12-2016)

\section{Pendahuluan}

Luas hutan Indonesia yang tergolong besar yaitu mencapai 120 juta ha atau $51.3 \%$ dari luas daratan wilayah menyimpan sumber daya alam hayati yang berlimpah (KLHK, 2015). Akan tetapi, pengelolaan yang kurang bijaksana mengakibatkan hutan Indonesia mengalami kerusakan, yang berdampak pada penurunan produktifitas hutan dalam menjalankan fungsinya. Laju deforestasi dan degradasi hutan pada periode 2009-2012 adalah sekitar 450,000 ha/tahun (FWI, 2011), dan pada periode 2009-2014 sekitar 9\% tutupan hutan berkurang dari 30.1 juta ha menjadi 27.2 juta ha (KLHK, 2015). Luas hutan yang berkurang berdampak secara tidak langsung terhadap perubahan iklim global. Oleh karena itu Indonesia telah berkomitmen untuk berperan aktif dalam Reducing Emissions from Deforestation and Forest Degradation (REDD) yang pada tahun 2010 berkembang menjadi $R E D D++$. Salah satu upaya yang dilakukan yaitu dengan melakukan restorasi ekosistem.

Upaya nyata yang dilakukan Indonesia dalam merestorasi ekosistem hutan yaitu dengan mengeluarkan Peraturan Pemerintah (PP) nomor 6 Tahun 2007, jo PP Nomor 3 Tahun 2008 yang menyatakan bahwa kegiatan restorasi ekosistem dalam hutan alam produksi dilakukan dalam kawasan Izin Usaha Pemanfaatn Hasil Hutan Kayu-Restorasi Ekosistem (IUPHHK-RE) (Kartodiharjo et al., 2014). Menurut Pera- turan Menteri Kehutanan Nomor: P.64/MenhutII/2014 IUPPHK-RE kegiatan restorasi dilakukan untuk mengembalikan unsur hayati (flora dan fauna) serta unsur non hayati (tanah, iklim, dan topografi) pada suatu kawasan kepada jenis yang asli, sehingga tercapai keseimbangan hayati dan ekosistemnya.

Salah satu perusahaan yang pertama kali melakukan restorasi ekosistem adalah PT REKI (Restorasi Ekosistem Indonesia). Perusahaan ini bertanggungjawab merestorasi Hutan Harapan (Harapan Rainforest), yang salah satu area konsesinya berada di Provinsi Sumatera Selatan dengan luas area $\pm 52,170$ ha. Hutan Harapan di wilayah Sumatera Selatan pada tahun 1970 sampai dengan 1990 merupakan area konsesi yang telah diekploitasi besar-besar yang menyebabkan hutan terdegradasi. Selain itu, Hutan Harapan di wilayah Sumatera Selatan termasuk kedalam 10\% dari hutan dataran rendah yang tersisa $(500,000 \mathrm{ha})$, bagian dari 34 konservasi hostpot keanekaragaman hayati dataran sunda internasional, kawasan burung endemik, habitat 26 spesies langka dan kritis untuk dilindungi serta tempat tinggal bagi masyarakat adat Batin Sembilan (indegeous people). Oleh karena itu, PT REKI mendapat mandat secara sah untuk melakukan pengelolaan habitat, perlindungan dan upaya restorasi ekosistem hutan (Burung Indonesia et al., 2014).

Restorasi yang dilakukan di Hutan Harapan ini salah satu upaya untuk mengurangi tingkat kerusakan ekosistem yang berbasis pada proses pemulihan veg- 
etasi. Proses pemulihan tersebut dapat diketahui dari kondisi tutupan kanopi atau vegetasi yang beragam. Kondisi tutupan vegetasi yang beragam dapat diklasifikasikan berdasarkan tingkat kerusakan. Klasifikasi tingkat kerusakan diduga melalui pendekatan kondisi tegakan khususnya nilai kerapatan. Menurut penelitian Htun et al. (2011) tingkat kerusakan semakin rendah seiring dengan meningkatnya nilai kerapatan tegakan suatu ekosistem. Selain itu tingkat kerusakan yang berbeda berpengaruh terhadap kondisi tegakan, seperti keanekaragaman hayati dan kekayaan jenis yang menjadi karakteristik ekologi suatu tegakan (Bishoff et al., 2005). Kondisi tutupan vegetasi merupakan salah satu informasi dasar yang sangat penting untuk diketahui, dan dapat dijadikan sebagai acuan dasar dalam penyusunan strategi restorasi.

Oleh karena itu perlu dilakukan penelitian mengenai Analisis Tipologi Tutupan Vegetasi sebagai Dasar Penyusunan Strategi Restorasi di Area IUPHHK-RE PT REKI dengan tujuan mengetahui kondisi dinamika perubahan ekosistem (suksesi), tingkat kerusakan, hubungan kedekatan antar tingkat permudaan, teknik silvikultur dan jenis tanaman terpilih dalam rangka upaya restorasi di area IUPHHK-RE PT REKI wilayah Sumatera Selatan.

\section{Metode}

\subsection{Lokasi dan Waktu Penelitian}

Penelitian ini dilakukan di area restorasi Hutan Harapan (PT REKI) yang berada di wilayah Sumatera Selatan, terletak diantara $103^{\circ} 27^{\prime} 00^{\prime \prime}-103^{\circ} 7^{\prime} 54^{\prime \prime}$ BT dan $02^{\circ} 23^{\prime} 51^{\prime \prime}-02^{0} 07^{\prime} 00^{\prime \prime}$ LS, dengan ketinggian tempat antara 30-70 mdpl. Lokasi penelitian secara administrasi kehutanan, termasuk kedalam Dinas Kehutanan Sekayu dan secara administrasi pemerintahan, termasuk kedalam wilayah Kecamatan Batanghari Liko, Kabupaten Musi Banyuasin, Provinsi Sumatera Selatan, serta termasuk dalam sub-DAS Meranti dan sub-DAS Kapas (Gambar 1). Waktu pelaksanaannya dimulai pada Juni 2016 sampai dengan Juli 2016.

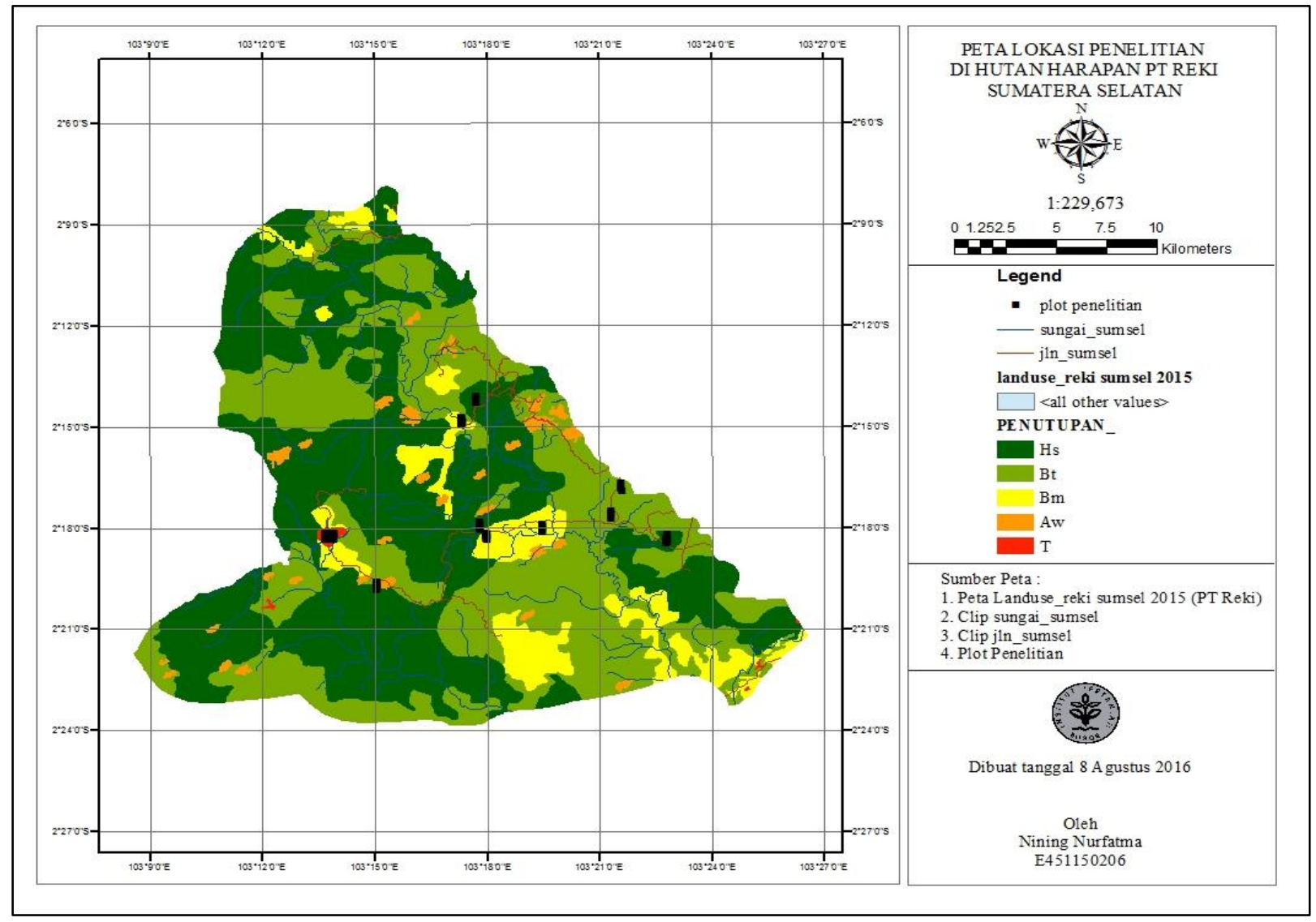

Gambar 1. Peta lokasi Penelitian Hutan Harapan Sumatera Selatan.

\subsection{Jenis dan Sumber Data}

Data yang digunakan bersumber dari data sekunder dan data primer yang berupa data spasial maupun non spasial. Data sekunder yang digunakan meliputi: data Inventarisasi Hutan Menyeluruh Berkala (IHMB) dan Risalah Hutan PT REKI, data jenis tanah, data curah hujan stasiun sekayu, peta tutupan lahan hutan hara- pan wilayah Sumatera Selatan, sedangkan data primer yang digunakan meliputi data analisis vegetasi tahun 2016.

\subsection{Metode Pengumpulan Data}

Pengumpulan data analisis vegetasi tahun 2016 diperoleh dengan melakukan observasi lapang. 
Pembuatan plot mempertimbangkan Peraturan Direktur Jenderal Pengelolaan Hutan Produksi Lestari (PHPL) Nomor: P.9/PHPL-SET/2015 dengan membuat lima buah plot berbentuk garis berpetak dengan jarak antar plot sebesar 100 meter, plot tersebut dibuat ditiga lokasi yang mewakili karakteristik dari empat tipologi (hutan sekunder, belukar tua, belukar mudan, dan eks HT akasia) yang ada di lokasi penelitian.

\subsection{Analisis Data}

\section{a. Analisis Vegetasi}

Analisis vegetasi dilakukan untuk mengetahui struktur dan komposisi jenis vegetasi yang ada di kawasan tersebut. Struktur tegakan dapat diketahui dengan distribusi jumlah pohon berdasarkan kelas diameter, stratifikasi tajuk dan sebaran permudaan (Indriyanto 2008). Komposisi jenis dapat diketahui dengan melakukan analisis data meliputi menghitung nilai Kerapatan Jenis (K), Kerapatan Relatif (KR), Frekuensi (F), Frekuensi Relatif (FR), Dominansi (D), dan Dominansi Relatif (DR) dengan rumus sebagai berikut:

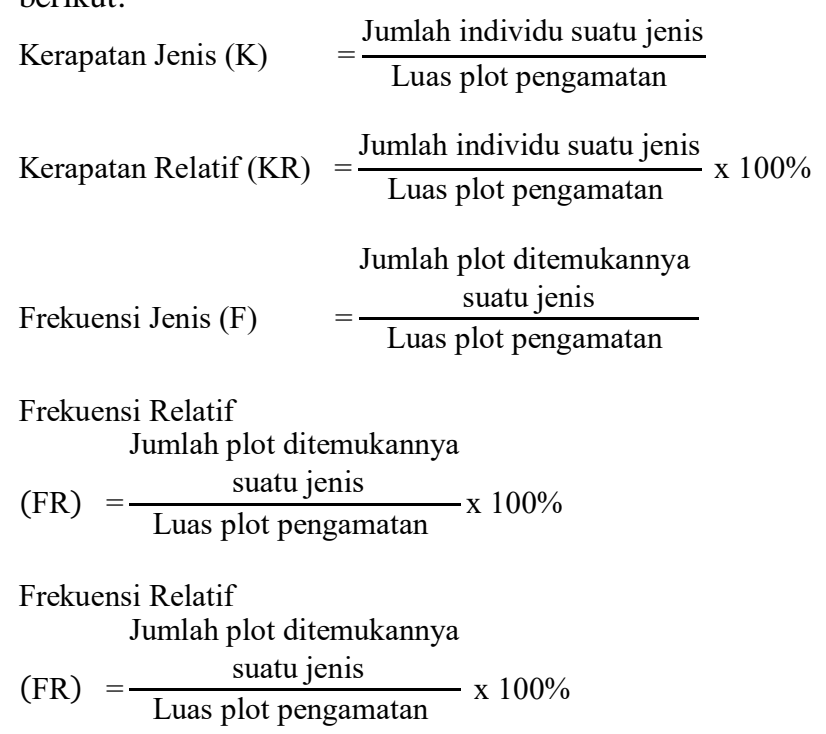

Dominansi Jenis (D) $\quad=\frac{\text { Dominasi suatu jenis }}{\text { Luas plot pengamatan }} \times 100 \%$

Dominansi Relatif $(D R)=\frac{\text { Dominasi suatu jenis }}{\text { Dominasi seluruh jenis }} \times 100 \%$

Indeks Nilai Penting (INP)

INP Semai $=\mathrm{KR}+\mathrm{FR}$

INP Pancang, Tiang, Pohon $=$ KR + FR + DR

Nilai Keanekaragaman jenis (H')

$\mathrm{H}^{\prime}=-\sum_{\mathrm{i}=1}^{\mathrm{S}} \mathrm{p}_{\mathrm{i}} \ln \left(\mathrm{p}_{\mathrm{i}}\right) \quad$ dimana $\quad \mathrm{p}_{\mathrm{i}}=\frac{\mathrm{n}_{\mathrm{i}}}{\mathrm{N}}=\frac{\mathrm{n}_{\mathrm{i}}}{\sum_{\mathrm{i}=1}^{\mathrm{s}} \mathrm{n}_{\mathrm{i}}}$

Keterangan :

$\mathrm{H}^{\prime} \quad=$ Indeks keanekaragaman jenis

$\mathrm{N} \quad=$ Total INP

ni $\quad=$ INP jenis ke-i, dan
Nilai kekayaan jenis (Dmg)

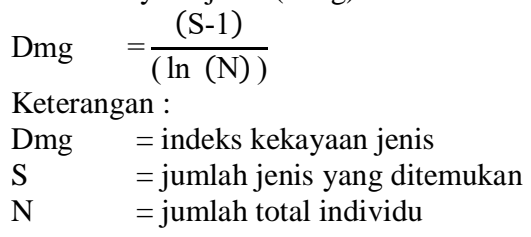

Nilai kemeratan jenis $(E)$

$\mathrm{E}^{\prime}=\mathrm{H}^{\prime} / \ln (\mathrm{S})$

Keterangan:

$\mathrm{E}^{\prime} \quad=$ indeks kemerataan jenis

H' = indeks keanekaragaman jenis tumbuhan

$\mathrm{S} \quad=$ jumlah jenis

Indeks Dominansi Jenis (ID)

$\mathrm{ID}=\sum_{\mathrm{i}=0}^{\mathrm{n}}\left(\frac{\mathrm{ni}}{\mathrm{N}}\right) 2$

Keterangan :

ID $\quad=$ indeks dominansi

ni $\quad=$ INP jenis $\mathrm{i}$

$\mathrm{N} \quad=$ total INP

Indeks kesamaan komunitas (IS)

$\mathrm{IS}=\frac{2 \mathrm{~W}}{\mathrm{a}+\mathrm{b}} \times 100 \%$

Keterangan :

IS = indeks kesamaan komunitas

$\mathrm{W}=$ jumlah nilai yang sama dan nilai terendah dari jenisjenis yang terdapat dalam dua tegakan yang dibandingkan $\mathrm{a}=$ jumlah nilai kuantitatif dari semua jenis yang terdapat pada komunitas pertama

$\mathrm{b}=$ jumlah nilai kuantitatif dari semua jenis yang terdapat pada komunitas kedua

\section{b. Analisis Kerusakan Hutan}

Analisis kerusakan hutan ini digunakan untuk mengklasifikasikan tingkat kerusakan yang ada di area restorasi Hutan Harapan (PT REKI) Sumatera Selatan, yang menjadi pertimbangan dalam penentuan teknik silvikultur yang tepat dalam melakukan upaya restorasi. Tahapan yang dilakukan meliputi perhitungan nilai kerapatan dan persen perubahan vegetasi dengan membandingkan nilai kerapatan setiap tipologi dengan nilai kerapatan tipologi hutan sekunder sebagai ekosistem referensi.

\section{c. Frekuensi Raunkaier}

Hukum Frekuensi Raunkaier digunakan untuk melihat penyebaran jenis dalam komunitas, yang diklasifikasikan kedalam lima kelas terlihat pada Tabel 1 (Misra, 1980). 
Tabel 1. Frekuensi sebaran jenis menurut hukum frekuensi Raunkaier

\begin{tabular}{cc}
\hline Klasifikasi & Jumlah jenis dengan frekuensi \\
\hline A & $1-20 \%$ \\
B & $21-40 \%$ \\
C & $41-60 \%$ \\
D & $61-80 \%$ \\
E & $81-100 \%$ \\
\hline
\end{tabular}

Komunitas hutan alam terdistribusi secara normal apabila:

$\mathrm{A}>\mathrm{B}>\mathrm{C}>\mathrm{D}<\mathrm{E}$; atau

$\mathrm{A}>\mathrm{B}>\mathrm{C}=\mathrm{D}<\mathrm{E}$; atau

$\mathrm{A}>\mathrm{B}>\mathrm{C}<\mathrm{D}<\mathrm{E}$

Berdasarkan huruf yang ditunjukkan, dapat diketahui kondisi penyebaran jenis dalam suatu komunitas, dengan kriteria sebagai berikut:

a) Komunitas tergolong homogen, apabila E > D

b) Komunitas tergolong terganggu, apabila $\mathrm{E}<\mathrm{D}$

c) Komunitas tergolong buatan, apabila A, E tinggi

d) Komunitas tergolong heterogen, apabila B, C, D tinggi

\section{d. Hubungan kedekatan antara tingkat permudaan}

Hubungan kedekatan antara tingkat permudaan dapat diketahui melalui dua metode yaitu:

\section{Analisis Kluster}

Analisis kluster atau disebut juga analisis gerombol digunakan dalam menggelompokkan objek pengamatan berdasarkan kesamaan yang dimiliki. Prinsip yang diterapkan dalam analisis ini adalah ukuran kedekatan atau kemiripan berdasarkan jarak euclidean (eucidean distance) dari setiap individu penyusun komposisi suatu ekosistem yang disajikadalam bentuk dendrogram (Ludwig \& Reynolds, 1988) dengan menggunakan software Minitab.

\section{Ordinansi Principal Components Analysis}

Principal Components Analysis (PCA) adalah salah satu metode ordinasi yang digunakan dalam ilmu ekologi. Prinsip PCA adalah menyederhanakan matriks yang komplek ke dalam suatu komponen sumbu orthogonal, menerjemahkan nilai Eigen dari varibel nilai yang tercatat dan dapat diterapkan untuk matriks yang menggunakan jarak eucladean. Metode ini merupakan teknik statistik yang secara linear mengubah bentuk sekumpulan variabel asli menjadi variabel yang lebih kecil yang tidak berkorelasi yang dapat mewakili informasi dari kumpulan variabel asli dan untuk menemukan variabel mana dalam kumpulan tersebut yang berhubungan dengan lainnya (Ludwig dan Reynolds, 1988). Data yang digunakan dalam analisis ini berupa data hasil perhitungan Indeks Similarity (IS) antar tingkat permudaan pada setiap tipologi, yang disajikan dalam bentuk loading plot dan scree plot atau keduanya (biplot) dengan menggunakan software Minitab.

\section{e. Jenis Spesies Prioritas}

Jenis prioritas dapat diketahui berdasarkan hasil analisis data sekunder maupun data primer. Data hasil analisis vegetasi akan dilakukan seleksi data mengenai jenis yang dipilih untuk prioritas restorasi. Jenis terpilih merupakan jenis-jenis asli (endemik) yang terdiri dari beberapa spesies untuk menghindari terjadinya dominasi suatu spesies (monokultur). Jenis yang terpilih hendaknya memiliki permudaan alam yang melimpah atau ketersediaan buah yang cukup banyak untuk dijadikan bahan tanaman (Sutomo, 2009).

\section{Hasil dan Pembahasan}

\subsection{Kondisi Umum}

a. Kondisi fisik wilayah

Kondisi fisik di areal restorasi hutan harapan wilayah Sumsel diklasifikasikan berdasarkan kondisi tutupan lahan, yaitu: Hutan lahan kering sekunder $(48.09 \%)$, belukar tua $(40.34 \%)$, belukar muda dan semak $(9.29 \%)$, tanah terbuka $(0.27 \%)$, awan $(2 \%)$. Klasifikasi tersebut didasarkan dari hasil interpretasi citra Landsat tahun 2015 yang disahkan oleh Direktur Inventarisasi dan Pemantauan Sumber Daya Hutan, Surat Nomor: S.410/IPSDH-2/2015 tanggal 10 Desember 2015.Kondisi topografi di areal sumsel 89\% tergolong datar (0-8\%) dan sekitar $11 \%$ bertopografi landai $(8-15 \%)$.

\section{b. Kondisi geologis dan klimatis}

Hutan harapan memiliki formasi geologi utama (air benakat, kasai, muaraenim) dan termasuk aluvial $(8 \%)$, latosol $(24 \%)$, planosol $(33 \%)$ dan podsolik $(35 \%)$. Klasifikasi iklim menurut Schmidt dan Ferguson, lokasi penelitian termasuk tipe iklim A (sangat basah) dengan pola distribusi hujan basah sepanjang tahun dengan nilai $\mathrm{Q}=0$ (tanpa bulan kering). Nilai $Q$ merupakan perbandingan antara jumlah rata-rata bulan kering $(<60 \mathrm{~mm})$ dan jumlah rata-rata bulan basah $(>100 \mathrm{~mm})$

\subsection{Kondisi Vegetasi}

\section{a. Struktur Tegakan}

Hutan hujan tropis disebut hutan heterogen tidak seumur (uneven-aged forest) dikarenakan setiap tapaknya memiliki komposisi jenis yang heterogen dengan struktur tegakan yang beragam. Struktur tegakan menunjukkan ketersediaan tegakan pada setiap kelas diameter (Muhdin et al., 2008). Struktur horizontal menunjukkan bahwa tipologi hutan sekunder dan belukar tua merupakan tegakan yang produktif (terlihat dari Gambar 2 yang berbentuk eksponensial negatif dengan nilai determinasi 0.98 dan 0.97), yang ditandai dengan kehadiran pohon berdiamater $40 \mathrm{~cm}$, selain itu ketersediaan tegakan yang tinggi pada pohon kelas diameter kecil menjamin kelangsungan tegakan dimasa mendatang apabila terjadi kerusakan pada pohon kelas diameter besar (Suwardi et al., 2013).

Nilai determinasi lebih besar dari 0.95 menunjukkan bahwa kontribusi nilai kelas diameter terhadap variasi (naik turunnya) nilai kerapatan di dua lokasi 
tersebut sebesar lebih dari 95\%, sedangkan sisanya kurang dari 5\% disebabkan oleh faktor lain (Supranto, 2009). Tipologi Eks HT akasia yang diteliti tidak dapat dibuat persamaan ekponensial karena jumlah pohon yang ditemukan hanya satu jenis yaitu Acacia mangium.
Struktur vertikal suatu tegakan dapat diketahui dari hubungan kerapatan dengan stratifikasi tajuk dan tingkat permudaan. Stratifikasi tajuk di plot penelitian disajikan dalam Tabel 2.
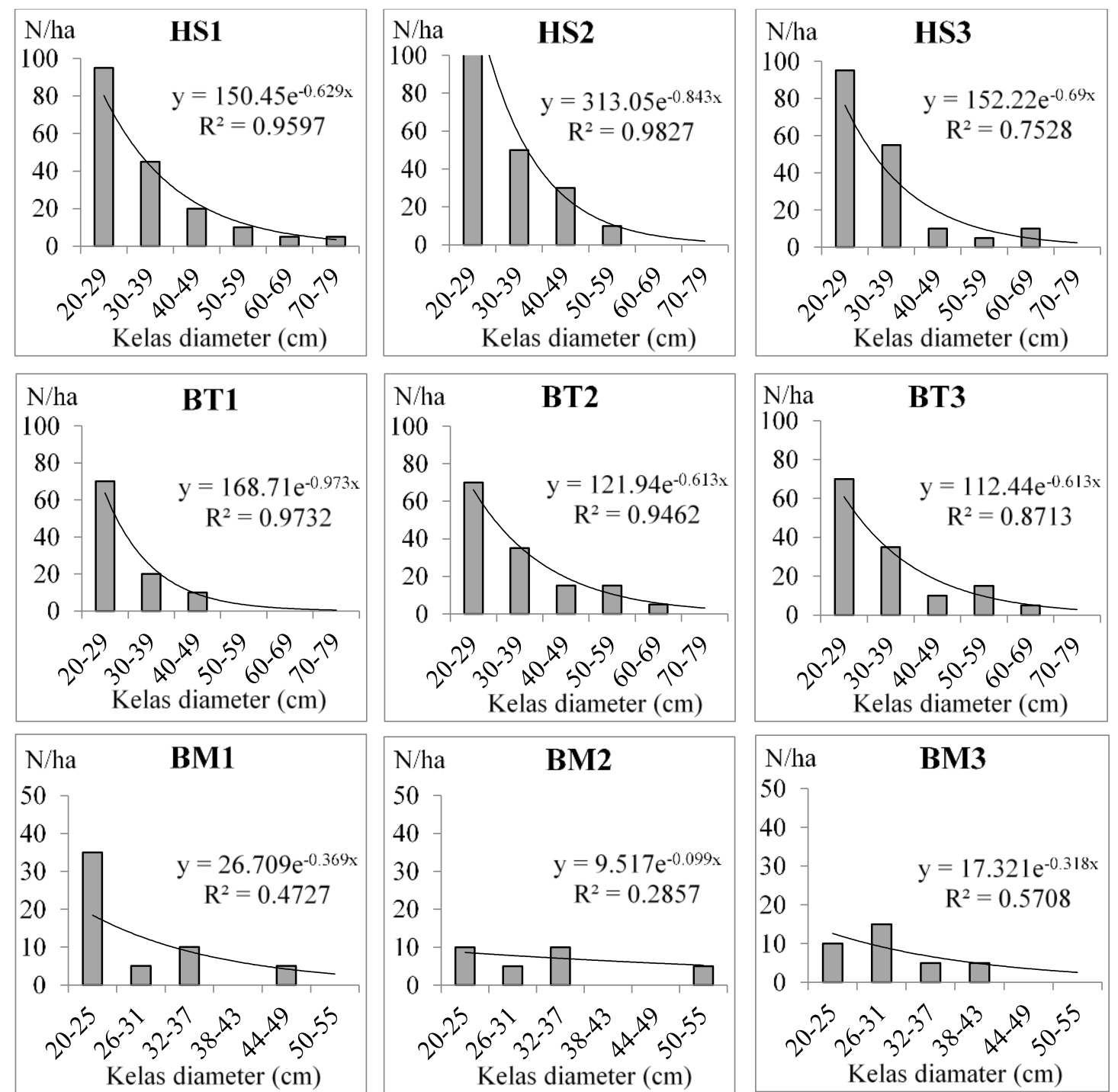

Gambar 2. Struktur tegakan berdasarkan kelas diameter di beberapa tipologi pada tingkat pohon

( Keterangan: belukar muda $=B M$, belukar tua $=B T$, hutan sekunder $=H S$ ) ${ }^{*}$ angka dibelakang huruf menunjukkan urutan lokasi.

Tabel 2. Nilai kerapatan berdasarkan stratifikasi tajuk (N/ha)

\begin{tabular}{|c|c|c|c|c|c|}
\hline \multirow[b]{2}{*}{ Tipologi } & \multicolumn{5}{|c|}{ Stratifikasi tajuk } \\
\hline & $\mathrm{A}(>30 \mathrm{~m})$ & B $(20-30 \mathrm{~m})$ & $\mathrm{C}(4-20 \mathrm{~m})$ & $\mathrm{D}(1-4 \mathrm{~m})$ & $\mathrm{E}(0-1 \mathrm{~m})$ \\
\hline Hutan sekunder & 30 & 120 & 688 & 4640 & 65500 \\
\hline Belukar tua & 8 & 60 & 438 & 5008 & 56250 \\
\hline Belukar muda & 0 & 15 & 188 & 2280 & 15750 \\
\hline Eks HT akasia & 0 & 0 & 5 & 1160 & 3827750 \\
\hline
\end{tabular}


Tabel 2 menunjukkan bahwa semua tipologi yang diamati menunjukkan bahwa nilai kerapatan tertinggi terdapat pada stratum E. Stratum E ini dominannya merupakan jenis permudaan tingkat semai. Stratifikasi A-C lebih banyak ditemukan di tipologi hutan sekunder. Hal ini mengindikasikan bahwa pada ti- pologi hutan sekunder terdapat pohon-pohon yang lapisan teratasnya mengalahkan atau menguasai pohon-pohon lebih rendah, yang menjadi penciri dari komunitas yang bersangkutan (Soerianegara \& Indrawan 2014)

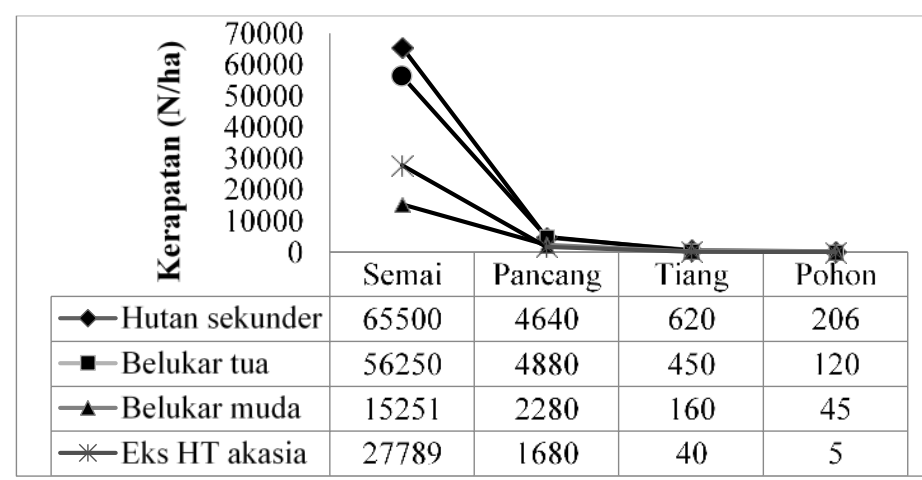

Gambar 3. Stuktur tegakan berdasarkan ketersedian tingkatan permudaan di beberapa tipologi.

Gambar 3 menunjukkan kurva $\mathbf{J}$ terbalik yang terbentuk disemua tipologi. Kurva tersebut menunjukkan bahwa kondisi hutan berada dalam kondisi yang seimbang dimana, tingkat pemudaan tersedia dalam jumlah yang cukup (tingkat semai >tingkat pancang>tingkat tiang>tingkat pohon) dan terjaminnya kelangsungan regenerasi dari permudaan tersebut (Dendang \& Handayani 2015).

\section{b. Komposisi jenis}

Lokasi penelitian yang diambil mempunyai karakteristik berbeda. Karakteristik yang berbeda pada setiap tipologi tentunya akan menciptakan susunan komposisi jenis yang berbeda. Peneliti melakukan klasifikasi jenis antara spesies pionir dan klimaks yang mengacu pada Ghazoul dan Sheil (2009).

Jenis klimaks yang mendominasi di tipologi hutan sekunder dari tingkat semai $\mathrm{s} / \mathrm{d}$ pohon meliputi merpayang (Scaphium macropodum), asam-asam (Baccaurea racemosa), bebras (Aporosa elmeri), darah-darah (Knema latifolia), renai (Antidesma montanum), kelat putih (Syzygium longiflorum), kemenyan (Styrax benzoin), rambutan (Nephelium cuspidatum, kayu gading (Hydnocarpus polypetala), kayu biaya- wak (Polyalthia rumphii), siluk (Gironniera hirta), medang telur (Alseodaphne malabonga), bidang (Artocarpus kemando), kempas (Koompassia malaccensis), sigam (Polyalthia beccarii), kayu kuning (Santiria griffithii), dan kelat merah (Syzygium laxiflorum).

Famili yang ditemukan sebagian besar hanya diwakili 1-3 spesies, famili yang memiliki jumlah spesies relatif banyak ( $\geq 3$ ) adalah famili Euphorbiaceae, salah satu jenis yang selalu hadir di berbagai tingkat permudaan dari famili tersebut adalah Bacaurea racemosa. Jenis ini memiliki nama lokal menteng/kepundung/bencoy yang termasuk kedalam tanaman budidaya yang dapat tumbuh sampai ketinggian $1.000 \mathrm{~m}$ dpl pada hampir semua tipe dan jenis tanah (Siregar 2005).

\section{c. Indeks Nilai Penting (INP)}

Peranan suatu jenis dalam komunitas dapat diketahui dari besar kecilnya Indeks Nilai Penting, dimana semakin tinggi INP yang dimiliki maka jenis tersebut semakin mendominasi. Hasil analisis INP dilokasi penelitian terlihat pada Tabel 3 .

Tabel 3. Hasil analisis INP pada semua tingkat permudaan dibeberapa tipologi

\begin{tabular}{|c|c|c|c|c|}
\hline \multirow{2}{*}{ Tipologi } & \multicolumn{4}{|c|}{ INP tingkat permudaan } \\
\hline & Semai & Pancang & Tiang & Pohon \\
\hline \multirow{3}{*}{$\begin{array}{c}\text { Hutan } \\
\text { sekunder }\end{array}$} & $\begin{array}{c}\text { Stachyphrynium repens } \\
(91 \%)\end{array}$ & Bellucia pentamera $(21 \%)$ & Gironniera hirta $(42 \%)$ & $\begin{array}{c}\text { Hydnocarpus polypetala } \\
(20 \%)\end{array}$ \\
\hline & Andira inermis (28\%) & Baccaurea racemosa (10\%) & Knema latifolia $(28 \%)$ & Syzygium laxiflorum (15\%) \\
\hline & & Antidesma montanum (10\%) & $\begin{array}{l}\text { Syzygium longiflorum } \\
(27 \%)\end{array}$ & \\
\hline \multirow{3}{*}{ Belukar tua } & $\begin{array}{c}\text { Macaranga gigantea } \\
(43 \%)\end{array}$ & Croton argyratus $(26 \%)$ & $\begin{array}{c}\text { Peronema canescens } \\
(37 \%)\end{array}$ & Peronema canescens $(34 \%)$ \\
\hline & Byttneria curtisii (18\%) & Macaranga trichocarpa (21\%) & Croton argyratus $(36 \%)$ & $\begin{array}{l}\text { Barringtonia scortechinii } \\
(33 \%)\end{array}$ \\
\hline & Aporosa elmeri (14\%) & Xylopia malayana $(12 \%)$ & $\begin{array}{c}\text { Lithocarpus bancanus } \\
(15 \%)\end{array}$ & Pertusadina multifolia (31\%) \\
\hline \multirow{2}{*}{$\begin{array}{l}\text { Belukar } \\
\text { muda }\end{array}$} & $\begin{array}{l}\text { Pyrrosia polydactyla } \\
(93 \%)\end{array}$ & Dendrocalamus sp (67\%) & $\begin{array}{l}\text { Lithocarpus bancanus } \\
(71 \%)\end{array}$ & Balakata baccata $(76 \%)$ \\
\hline & $\begin{array}{c}\text { Clidemia hirta } \\
(35 \%)\end{array}$ & Hevea brasiliensis (17\%) & $\begin{array}{l}\text { Nephelium cuspidatum } \\
(68 \%)\end{array}$ & Lithocarpus elegans $(75 \%)$ \\
\hline
\end{tabular}




\begin{tabular}{|c|c|c|c|c|}
\hline \multirow{3}{*}{ Tipologi } & \multicolumn{4}{|c|}{ INP tingkat permudaan } \\
\hline & Semai & Pancang & Tiang & Pohon \\
\hline & $\begin{array}{c}\text { Psychotria viridiflora } \\
(23 \%)\end{array}$ & $\begin{array}{c}\text { Gigantochloa scortechinii } \\
(200 \%)\end{array}$ & $\begin{array}{c}\text { Elaeocarpus stipularis } \\
(42 \%)\end{array}$ & $\begin{array}{c}\text { Dysoxylum arborescens } \\
(42 \%)\end{array}$ \\
\hline \multirow{2}{*}{$\begin{array}{l}\text { Eks HT } \\
\text { akasia }\end{array}$} & $\begin{array}{c}\text { Imperata cylindrica } \\
(102 \%)\end{array}$ & Acacia mangium (119\%) & Acacia mangium $(300 \%)$ & Acacia mangium $(300 \%)$ \\
\hline & $\begin{array}{c}\text { Ageratum conyzoides } \\
(73 \%)\end{array}$ & Dendrocalamus sp. (67\%) & & \\
\hline
\end{tabular}

Hasil perhitungan INP di seluruh tingkat permudaan yang memiliki nilai INP yang lebih dari 10 mengindikasikan bahwa terdapat jenis dominan yang memanfaatkan kondisi lingkungan secara optimal dan efisien sehingga ketahanan dan pertumbuhan dari jenis tersebut lebih stabil dibandingkan jenis yang lain (Mawazin dan Subiakto, 2013). Jenis-jenis dominan tersebut menjadi penciri kondisi ekosistem, pada tipologi eks HT akasia vegetasi alang-alang (I.cylindrical) dan semak-semak kecil (A.conyzoides) mendominasi di lokasi tersebut. Hal ini menunjukkan proses suksesi pada areal terganggu diawali dengan pertumbuhan jenis rerumputan. Kemudian muncul belukar dan herba dari famili Melastomataceae (C.hirta) dan Polypodiaceae (P.polydactyla) yang ditemukan pada tipologi belukar muda. Selanjutnya akan tumbuh pohon hutan sekunder seperti jenis pioneer Macaranga, Baccaurea yang ditemukan pada tipologi belukar tua. Terakhir, akan tumbuh jenis-jenis Dipterocarpaceae (Shorea sp.) yang ditemukan pada tipologi hutan sekunder tua (Soerianegara dan Indrawan, 2014). Dominansi jenis di belukar tua dan hutan sekunder yang tidak sesuai dengan Soerianegara dan Indrawan (2014) diduga karena proses suksesi yang belum mencapai klimaks dimana tegakan masih didominasi oleh jenis-jenis yang intoleran (tidak tahan naungan).

\section{d. Nilai indeks keanekaragaman (H'), kekayaan}

(DMg), kemerataan (E), dominansi (ID)

Perhitungan nilai indeks keanekaragaman, kekayaan, kemerataan dan dominasi bertujuan untuk mengetahui kondisi vegetasi di dalam suatu komunitas. Hasil perhitungan keempat indeks tersebut disajikan pada Tabel 4. Tabel 4 menunjukkan nilai indeks H', Dmg, dan E untuk tingkat pohon terbesar berada pada tipologi hutan sekunder sedangkan terendah pada eks HT akasia. Hal ini dikarenakan jumlah spesies yang temukan di hutan sekunder lebih banyak dan tersebar secara merata serta interaksi spesies yang terjadi tergolong tinggi dibandingkan tipologi lain, sehingga mempengaruhi dari tiga nilai indeks tersebut. Selain itu nilai keragaman yang tinggi menunjukkan bahwa ekosistem hutan sekunder merupakan ekosistem yang stabil terhadap gangguan. Kemudian nilai ID berbanding terbalik dengan tiga nilai lainnya, dimana terendah terdapat pada tipologi hutan sekunder dan tertinggi pada Eks HT akasia. Hal ini diduga karena pada tipologl eks HT akasia khususnya tingkat pohon terjadi penguasaan oleh jenis Acacia mangium, sedangkan di hutan sekunder spesies tersebar merata (Indriyanto, 2006).

\subsection{Analisis Kerusakan Hutan}

Klasifikasi tingkat kerusakan dilakukan dengan menggunakan pendekatan nilai kerapatan, dimana tingkat kerusakan dapat diduga dari perhitungan persentase perubahan vegetasi. Persentase tersebut dapat dihitung dengan menggunakan data hasil ground check dari tipologi hutan sekunder sebagai acuan atau data pembanding terhadap tiga tipologi lainnya. Hasil perhitungan persen perubahan vegetasi dapat dilihat pada Tabel 5.

Tabel 5 menunjukkan bahwa persentase perubahan kerapatan terbesar diduga berada pada tipologi eks HT akasia, sedangkan yang terendah berada pada hutan sekunder. Nilai persen perubahan kerapatan menjadi landasan dalam klasifikasi tingkat kerusakan. Urutan tipologi berdasarkan tingkat kerusakan dari tinggi ke rendah meliputi: tipologi eks HT akasia dan belukar muda (tinggi), belukar tua (sedang), hutan sekunder (rendah).

Hasil ini sesuai dengan dugaan Onrizal et al. (2005) yang menyatakan bahwa antara nilai kerapatan vegetasi dengan tingkat kerusakan terdapat suatu hubungan. Hal ini didukung oleh hasil penelitian Iskandar et al. (2012) yang menunjukkan hubungan yang berbanding terbalik antara nilai kerapatan vegetasi dengan tingkat kerusakan. Tingkat kerusakan yang berbeda diduga karena gangguan dan kondisi yang berbeda (Partomihardjo, 2011), dimana pada tipologi Eks HT akasia disebabkan oleh kebakaran hutan dengan intensitas tinggi di tahun 2015.

Kemudian pada belukar muda diduga terdapat beberapa jenis tanaman yang mati karena kondisi persaingan hara dan cahaya yang cukup tinggi antara tanaman pionir dengan jenis bambu. Selanjutnya pada belukar tua terjadi penurunan diduga karena adanya beberapa lokasi yang memiliki kondisi vegetasi hampir menyerupai tipologi hutan sekunder yang ditandai dengan kelimpahan jenis klimaks yang hampir menyeluruh. Terakhir pada hutan sekunder kondisi persaingan lebih stabil dimana pada fase ini jenis semi toleran dan intoleran mulai menempati kondisi klimaks. 
ISSN 2086-4639 | e-ISSN 2460-5824 JPSL Vol. 7 (1): 41-50

Tabel 4. Nilai indeks keanekaragaman (H'), kekayaan(DMg), kemerataan (E), dominansi (ID) tingkat permudaan pada setiap tipologi hutan

\begin{tabular}{|c|c|c|c|c|}
\hline Tipologi & $\mathrm{H}^{\prime}$ & $\mathrm{DMg}$ & $\mathrm{E}$ & ID \\
\hline \multicolumn{5}{|l|}{ Semai } \\
\hline Hutan sekunder & $3.49^{\mathrm{T}}$ & $10.95^{\mathrm{T}}$ & $0.94^{\mathrm{T}}$ & $0.47^{\mathrm{s}}$ \\
\hline Belukar tua & $3.16^{\mathrm{T}}$ & $9.15^{\mathrm{T}}$ & $0.90^{\mathrm{T}}$ & $0.07^{\mathrm{R}}$ \\
\hline Belukar muda & $2.68^{\mathrm{s}}$ & $5.96^{\mathrm{T}}$ & $0.93^{\mathrm{T}}$ & $0.08^{\mathrm{R}}$ \\
\hline Eks HT akasia & $2.25^{\mathrm{s}}$ & $6.11^{\mathrm{T}}$ & $0.76^{\mathrm{T}}$ & $0.18^{\mathrm{R}}$ \\
\hline \multicolumn{5}{|l|}{ Pancang } \\
\hline Hutan sekunder & $3.42^{\mathrm{T}}$ & $9.61^{\mathrm{T}}$ & $0.97^{\mathrm{T}}$ & $0.04^{\mathrm{R}}$ \\
\hline Belukar tua & $3.20^{\mathrm{T}}$ & $8.79^{\mathrm{T}}$ & $0.94^{\mathrm{T}}$ & $0.06^{\mathrm{R}}$ \\
\hline Belukar muda & $1.78^{\mathrm{R}}$ & $3.50^{\mathrm{s}}$ & $0.83^{\mathrm{T}}$ & $0.24^{\mathrm{R}}$ \\
\hline Eks HT akasia & $1.50^{\mathrm{R}}$ & $2.49^{\mathrm{R}}$ & $0.93^{\mathrm{T}}$ & $0.24^{\mathrm{R}}$ \\
\hline \multicolumn{5}{|l|}{ Tiang } \\
\hline Hutan sekunder & $3.01^{\mathrm{T}}$ & $6.68^{\mathrm{T}}$ & $0.98^{\mathrm{T}}$ & $0.05^{\mathrm{R}}$ \\
\hline Belukar tua & $2.68^{\mathrm{s}}$ & $8.92^{\mathrm{T}}$ & $0.97^{\mathrm{T}}$ & $0.08^{\mathrm{R}}$ \\
\hline Belukar muda & $1.81^{\mathrm{R}}$ & $2.93^{\mathrm{R}}$ & $0.98^{\mathrm{T}}$ & $0.17^{\mathrm{R}}$ \\
\hline Eks HT akasia & $0.00^{\mathrm{R}}$ & $0.00^{\mathrm{R}}$ & $0.00^{\mathrm{R}}$ & $1.00^{\mathrm{T}}$ \\
\hline \multicolumn{5}{|l|}{ Pohon } \\
\hline Hutan sekunder & $3.41^{\mathrm{T}}$ & $8.94^{\mathrm{T}}$ & $0.99^{\mathrm{T}}$ & $0.04^{\mathrm{R}}$ \\
\hline Belukar tua & $2.81^{\mathrm{s}}$ & $5.87^{\mathrm{T}}$ & $0.98^{\mathrm{T}}$ & $0.07^{\mathrm{R}}$ \\
\hline Belukar muda & $2.07^{\mathrm{s}}$ & $3.48^{\mathrm{s}}$ & $0.99^{\mathrm{T}}$ & $0.14^{\mathrm{R}}$ \\
\hline Eks HT akasia & $0.00^{\mathrm{R}}$ & $0.00^{\mathrm{R}}$ & $0.00^{\mathrm{R}}$ & $1.00^{\mathrm{T}}$ \\
\hline
\end{tabular}

Keterangan: R (rendah), S (sedang), T (tinggi).

Tabel 5. Dugaan persentase perubahan tutupan vegetasi dibeberapa tipologi

\begin{tabular}{lccc}
\multicolumn{1}{c}{ Tipologi } & Kerapatan (N/ha) & $\begin{array}{c}\text { Kisaran nilai kerapatan } \\
\text { (N/ha) }\end{array}$ & $\%$ perubahan \\
& 206 & $185-226$ & $\pm 100.00^{*}$ \\
Hutan sekunder & 120 & $100-140$ & \pm 58.25 \\
Belukar tua & 45 & $30-60$ & \pm 21.84 \\
Belukar muda & 5 & $0-5$ & \pm 2.43 \\
Eks HT akasia & 5 &
\end{tabular}

\subsection{Hukum Frekuensi Raunkaier}

Hasil analisis menunjukkan kelas frekuensi Raunkaier di lokasi penelitian sebagai berikut: $\mathrm{A}>\mathrm{B}>\mathrm{C}=\mathrm{D}=\mathrm{E}$ (tipologi hutan sekunder $\mathrm{A}=25, \mathrm{~B}=5$, $\mathrm{C}, \mathrm{D}, \mathrm{E}=0$, belukar tua $\mathrm{A}=7, \mathrm{~B}=2, \mathrm{C}, \mathrm{D}, \mathrm{E}=0$ belukar muda $\mathrm{A}=7, \mathrm{~B}, \mathrm{C}, \mathrm{D}, \mathrm{E}=0$, eks HT akasia $\mathrm{A}=1$, $\mathrm{B}, \mathrm{C}, \mathrm{D}, \mathrm{E}=0$ ) yang berarti semua tipologi berdasarkan sebaran jenisnya tidak tersebar secara normal dan dominan nilai A yang tinggi mengindikasikan diseluruh tipologi mengalami gangguan. Oleh karena itu dilakukan analisis lanjut secara cluster untuk mengetahui hubungan antar tingkat permudaan.

\subsection{Hubungan kedekatan antar tingkat permudaan}

a. Analisis Kluster
Data analisis yang digunakan merupakan nilai IS pada tingkat permudaan di beberapa tipologi yang di teliti. Pengelompokkan atau clustering ini didasarkan pada euclidean distance untuk mengetahui hubungan asosiasi dari variabel yang diobservasi (Zuur et al., 2007). Kedekatan hubungan yang terbentuk dapat diketahui dari besar kecilnya jarak euclidean, dimana semakin kecil jarak yang terbentuk maka semakin erat hubungan yang terjalin. Rata-rata jarak yang digunakan sebesar 3.31, berdasarkan jarak tersebut terlihat bahwa antara tipologi eks HT akasia dengan tipologi lainnya tidak memiliki hubungan yang erat. Hal ini diduga karena komposisi penyusun antara tipologi eks HT akasia dengan tipologi lainnya sangat berbeda, sehingga mempengaruhi nilai kesamaan yang dihasilkan. 


\section{b. Prinsipal Component Analysis}

Prinsipal Component Analysis yang dilakukan untuk mengetahui hubungan kedekatan antar tingkat permudaan dikhususkan pada hubungan nilai kesamaan (indeks similiarty) antara tingkat semai dengan pohon. Hal ini diduga karena proses regenerasi suatu vegetasi didukung oleh keberadaan permudaan khususnya pada tingkat semai. Hasil analisis mengenai hubungan kedekatan antar semai dan pohon dibeberapa tipologi disajikan pada Gambar 4.

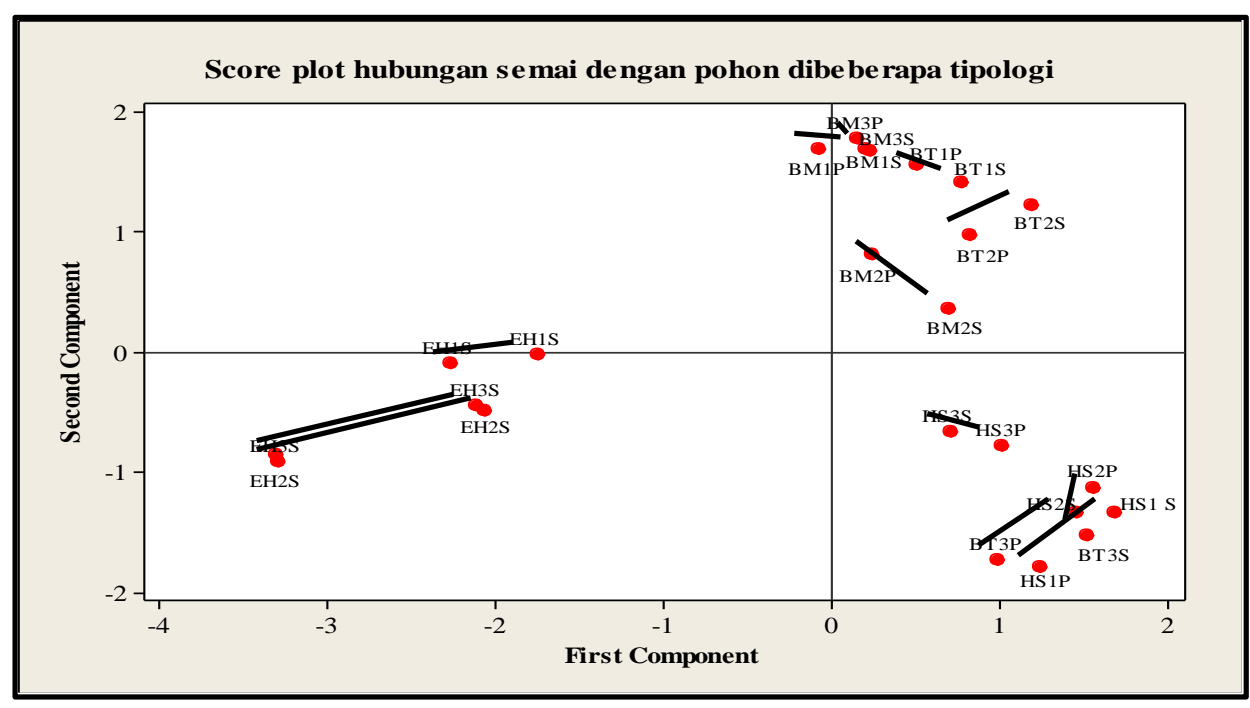

Gambar 4. Score plot hubungan semai dan pohon di beberapa tipologi (Ket: eks HT akasia=EH, belukar muda=BM, belukar tua =BT, hutan sekunder=HS, *angka dibelakang huruf menunjukkan urutan lokasi).

Gambar 4 menunjukkan titik semai dengan pohon di beberapa tipologi, dimana semakin dekat titik yang digambarkan maka mengindikasikan adanya hubungan. Hasil analisis korelasi menunjukkan bahwa hubungan korelasi di semua tipologi (terkecuali tipologi lahan terbuka lokasi dua dan tiga) memiliki nilai korelasi yang sangat tinggi $(r>0.90)$.

\subsection{Teknik silvikultur dan jenis prioritas}

Teknik silvikultur yang dapat dilakukan harus mempertimbangkan tingkat kerusakan yang terjadi. Tipologi eks HT akasia berdasarkan citra termasuk kedalam tipologi lahan terbuka, akan tetapi intensitas kebakaran yang tinggi menyebabkan tingkat kerusakan tergolong tinggi hal ini menyebabkan jenis alangalang mendominasi pada tingkat semai dan akasia mendominasi pada tingkat pancang (kerapatan dilokasi pertama 480/ha, lokasi ketiga 1780/ha) Menurut Heriansyah et al., (2007) biomassa dan volume jenis akasia di hutan Sumatera Selatan mencapai produksi maksimal pada umur tanaman muda. Oleh karena itu perlu upaya pembebasan jenis akasia dan perlu dilakukan penanaman (enrichment planting) jenis asli yang bersifat pioner. Salah satunya penanaman jenis macaranga (Macaranga sp.). Kemudian setelah tutupan tajuk terbentuk atau cahaya matahari masuk kedalam tajuk sebesar $40 \%$ maka dilakukan penanaman jenis semi klimaks salah satunya jenis Baccaurea sp.

Tingkat kerusakan pada tipologi belukar muda tergolong tinggi diduga karena kerusakan yang diakibatkan oleh ilegal logging sehingga jumlah individu dari jenis klimaks pada semua tingkat permudaan tidak lebih dari 1 individu, dan pada tingkat pancang didominasi oleh komunitas bambu (kerapatan dilokasi pertama 1040/ha, kerapatan dilokasi kedua 1680/ha). Intervensi silvikultur yang dapat dilakukan pengkayaan jumlah jenis dan jumlah individu dari jenis klimaks, dengan cara menanam jenis asli dalam jalur yang bernilai ekonomis, mampu beradaptasi diberbagai kondisi, mudah dikembangkan, cepat tumbuh dan tahan naungan (Pamoengkas, 2011). Jenis terpilih untuk penanaman adalah jenis spesies kunci yang tersedia dilokasi tetapi dalam jumlah yang sedikit (Koompassia malaccensis dan Nephelium sp.) dan pengkayaan jenis klimaks yang ditemukan di belukar tua tetapi tidak ditemukan belukar muda (Palaquium gutta, Hopea mengarawan, Shorea leprosula).

Selanjutnya tingkat kerusakan pada tipologi belukar tua dan hutan sekunder tergolong sedang dan rendah. Kondisi hutan klimaks umumnya dicirikan dengan pertumbuhan jenis klimaks dari famili Dipterocarpaceae. Famili tersebut tidak ditemukan di semua tingkat permudaan di tipologi belukar tua dan hutan sekunder lokasi ketiga diduga karena jenis famili ini termasuk kedalam kategori kayu komersial yang diekspoitasi secara luas pada tahun 1970-1990an. Oleh karena itu upaya penanaman beberapa jenis dari famili Dipterocarpaceae sangat diperlukan, sedangkan pada tipologi hutan sekunder perlu pengawasan agar suksesi alami yang sedang terjadi tidak mengalami gangguan. Salah satu jenis yang perlu ditanam di belukar tua adalah jenis S.leprosula, dimana jenis ini termasuk kedalam salah satu jenis kunci yang mendominasi pada ekosistem referensi.

Pemilihan jenis prioritas restorasi didasarkan pada data jenis pohon hasil uji petik yang termuat dalam ringkasan eksekutif analisis dampak lingkungan (AMDAL) PT REKI, dimana jenis Macaranga sp. merupakan jenis pionir yang mampu tumbuh di berbagai tempat tumbuh baik di hutan produktif mau- 
pun kurang produktif. Kemudian untuk jenis $K$. malaccensis dan Nephelium sp merupakan jenis pakan satwa yang sangat berperan penting dalam kelangsungan hidup satwa liar, dimana jenis beruang madu, lebah madu, dan burung pemakan biji umumnya menjadikan pohon kempas sebagai tempat bersarang, sedangkan pohon rambutan merupakan sumber penghasil buah yang bermanfaat bagi kelangsungan hidup satwa salah satunya jenis monyet. Kemudian jenis P.gutta, H.mengarawan, dan S.leprosula termasuk kedalam jenis kayu komersial, dua diantaranya termasuk kedalam jenis Dipterocarpacea yang langka dan dilindungi.

\section{Kesimpulan dan Saran}

\subsection{Kesimpulan}

Kondisi vegetasi di hutan sekunder cenderung stabil yang ditunjukkan dengan nilai H', Dmg, E yang tinggi, sedangkan di tipologi lainnya nilai tersebut menurun seiring dengan keterbukaan tajuk. Urutan tingkat kerusakan dari tinggi ke rendah meliputi tipologi eks HT akasia, belukar muda, belukar tua dan hutan sekunder. Hubungan tingkat permudaan bervariatif setiap tipologi, sedangkan hubungan antara semai dan pohon berkorelasi kuat di semua tipologi. Teknik silvikultur yang perlu dilakukan adalah pembebesan jenis A.mangium pada tipologi eks HT akasia, penanaman pada semua tipologi terkecuali hutan sekunder, sebagai upaya memperkaya jumlah individu dari jenis klimaks di tipologi belukar muda dan memperkaya jumlah jenis di belukar tua. Jenis tanaman terpilih untuk restorasi meliputi Macaranga sp., K.malaccensis, Nephelium sp., P.gutta, H.mengarawan, S.leprosula.

\subsection{Saran}

Identifikasi mengenai jenis prioritas restorasi perlu dipertimbangkan dari berbagai aspek salah satunya kualitas tempat tumbuh. Kualitas tumbuh berpengaruh terhadap kesesuaian jenis yang tumbuh. Jenis yang tumbuh akan mempengaruhi struktur dan komposisi yang terbentuk.

\section{Daftar Pustaka}

[1] Bischoff, W. D. M. Newberry, M. Lingenferder, R. Schnaeckel, G. H. Petol, L. Madani, C. E. Risdale, 2005. Secondary Succesion and dipterocarpaceae recruitment in Borneo Rain forest after logging. Forest Ecology Management 218 (2005), pp.174-192.

[2] Burung Indonesia, Royal Societ for Protection of the Birds, Harapan Rainforest Management Unit, 2014. Rencana Pengelolaan Strategi Hutan Harapan 2014-2040. PT REKI, Bogor.

[3] Dendang B., W. Handayani, 2015. Struktur dan komposis tegakan hutan di Taman Nasional Gunung Gede Pangrango, Jawa Barat. Pros Sem Nas Masy Biodiv Indon. 4 (1), pp.691695.

[4] [FWI] Forest Watch Indonesia, 2011. Potret Keadaan Hutan Indonesia Periode 2009-2013. Forest Watch Indonesia, Bogor.
[5] Ghazoul, J., D. Sheil, 2009. Tropical Rain Forest Ecology, Diversity, and Conservation. Oxford University Press, New York.

[6] Heriansyah, I., I. Miyakuni, T. Kato, Y. Kiyono, Y. Kanazawa, 2007. Growth characteristics and biomass of Acacia mangium under different management practices in Indonesia. Journal of Tropical Forest Science 19 (4), pp 226-235.

[7] Htun, N.Z., N. Mizoue, S. Yoshida, 2011. Tree species composition and diversity at different levels of disturbance in Popa Mountain Park, Myanmar. Biotropica 43 (5), pp. 597603.

[8] Indriyanto, 2008. Ekologi Hutan. PT Bumi Aksara, Jakarta.

[9] Indriyanto, 2006. Pengantar Budidaya Hutan. PT Bumi Aksara, Jakarta.

[10] Katrodiharjo, H., Bismak, I. Heriansyah, M. Silalahi, A.U. Budi, K. Zaini, Asmul, A. Ayat, Andriansyah, S. Sitorus, Y. Cahyadin, 2014. Naskah Akademik Rancangan Peraturam Pengelolaan Izin Usaha Pemanfaatan Hasil Hutan Kayu Restorasi Ekosistem. PT REKI, Jambi.

[11] [KLHK] Kementrian Lingkungan Hidup dan Kehutanan, 2015. Statistik Kementrian Lingkungan Hidup dan Kehutanan 2014. KLHK, Jakarta.

[12] Ludwig, A.J, F.J. Reynolds, 1998. Statistical Ecology. Wiley \& Sons Inc, New York.

[13] Mawazin, A. Subiakto, 2013. Keanekaragaman dan komposisi jenis permudaan alam hutan rawa gambut bekas tebangan di Riau. Forest Rehabilitation Journal 1 (1), pp. 59-73.

[14] [Menhut] Menteri Kehutanan. 2014. Peraturan Menteri Kehutanan Nomor: P.64/Menhut-II/2014 tentang Penerapan Silvikultur dalam Area Izin Usaha Pemanfaatan Hasil Hutan Kayu Restorasi Ekosistem pada hutan Produksi. Kementrian Kehutanan, Jakarta

[15] Misra, C.K, 1980. Manual of Plant Ecology. 2nd ed. Oxford and IBH Publishing Co, New Delhi.

[16] Muhdin, E. Suhendang, D. Wahjono, H. Purnomo, Istomo, dan B. C. H Simangunsong, 2008. Keragaman struktur tegakan hutan alam sekunder. Jurnal Manajemen Hutan Tropika 14 (2), pp. 81-87.

[17] Pamoengkas, P., 2011. Tinjauan silvikultur dan penerapannya dalam pengelolaan hutan alam produksi. Di dalam Sabaruddin, U. Wiharjo, A. Satya, D. Pirnanda. Prosiding Lokakarya Nasional Membangun Strategi Pengelolaan Restorasi Ekosistem di Hutan Produksi; 2011 Okt 11-12; Palembang, Indonesia. PT REKI, Palembang, pp. 24-34.

[18] Siregar, N, 2005. Atlas Benih Tanaman Hutan Indonesia. Jilid V. Balai Penelitian Teknologi Perbenihan, Bogor.

[19] Soerianegara, I., A. Indrawan. 2014. Ekologi Hutan Indonesia. Laboratorium Ekologi Hutan, Fakultas Kehutanan, IPB, Bogor.

[20] Supranto, J, 2009. Statistik: Teori dan Aplikasi Edisi Ketujuh. Erlangga, Jakarta.

[21] Sutomo, 2009. Kondisi vegetasi dan panduan inisiasi restorasi ekosistem hutan di bekas area kebakaran Bukit Pohen Cagar Alam Batukahu Bali (suatu kajian pustaka). Jurnal Biologi 8 (2), pp. 45-50.

[22] Suwardi, A. B., E. Mukhtar, Syamsuardi, 2013. Komposisi jenis dan cadangan karbon di hutan tropis dataran rendah, Ulu Gadut, Sumatera Barat. Berita Biologi 12 (2), pp. 169176.

[23] Zuur, A.F., E. N. Ieonp, G.M Smith, 2007. Analysing Ecological Data. Springer Science, New York. 